\title{
OPTIMIZATION OF THE PROCESS OF MANUFACTURING FORMATED POTATOES CHIPS
}

\author{
A. Kovtun, V. Kovbasa, O. Seidykh \\ National University of Food Technologies
}

\begin{tabular}{l} 
Key words: \\
Chips \\
Potato grains \\
Bran \\
Squeezed pumpkin seeds \\
Regression equation \\
Optimization \\
\hline
\end{tabular}

Article history:

Received 15.05.2018

Received in revised form 08.06.2018

Accepted 15.06.2018

Corresponding author:

A. Kovtun

E-mail:

kovtunav@ukr.net

\begin{abstract}
The article is devoted to the development of a regression model of optimal parameters for the production of molded potato chips due to the requirements of nutritiology. Potato grits, rye bran, barley, squeezed pumpkin seeds were used to develop the technology of molded potato chips. The processing of the results was carried out by the method of a complete factor experiment, which gave the opportunity to describe mathematically the investigated process in some local area of the factor space, which lies around the selected point.

Three factors were taken for the development of the regression equation: $X_{1}$ - is the degree of cutting of bran, $\mathrm{mr} ; X_{2}$ - temperature of baking-drying, ${ }^{\circ} \mathrm{C} ; X_{3}$ - quantity of added water, $\mathrm{ml}$.

To verify the significance of the regression coefficients, additional parallel experiments were performed to determine the reproducibility variance. Therefore, in each point of the factor space a serie of three experiments was conducted. The homogeneity of the variance was checked by the Cochran criterion and compared to the table values.

The statistical processing of experimental data consisted of calculating the coefficients of the regression equation and checking their significance. The founded coefficients of the regression equation were evaluated for statistical significance. The assessment was conducted according to Student's criterion. The obtained regression equation was checked for the adequacy of the investigated object, that is, its ability to adequately describe the surface of the response. The adequacy of the model was checked by Fischer's criterion. As a result of the experiment, regression equations were obtained in coded and natural form. On the basis of the obtained dependences graphic interpretation of mathematical model was carried out as isosurfaces of review.

Application of methods of mathematical modeling allowed to obtain the parameters of production of molded potato chips with high nutritional value with given structural and mechanical parameters that will affect the strength of the final product.
\end{abstract}

DOI: $10.24263 / 2225-2924-2018-24-3-24$ 


\title{
ОПТИМІЗАЦІЯ ПРОЦЕСУ ВИРОБНИЦТВА ФОРМОВАНИХ КАРТОПЛЯНИХ ЧИПСІВ
}

\author{
А.В. Ковтун, В.М. Ковбаса, О.Л. Сєдих \\ Національний університет харчових технологій
}

Стаття присвячена розробиі регресійної моделі оптимальних параметрів виробництва формованих картопляних чипсів, що відповідають вимогам нутрииіології. Для розроблення технології формованих картопляних чипсів використовували картопляну крупку, висівки жита, ячменю, жмих гарбузового насіння. Обробку результатів здійснювали методом повного факторного експерименту, який дав можливість математично описати досліджуваний процес у певній локальній області факторного простору, щэо лежить навколо обраної точки.

Для розроблення рівняння регресії було взято три фактори, щьо впливають на структурно-механічні показники (міцність) чипсів: $X_{1}-$ ступінь подрібнення висівок, мкм; $X_{2}$ - температура випікання-висушування, ${ }^{\circ} \mathrm{C} ; \mathrm{X}_{3}-$ кількість доданої води, мл.

Для перевірки значущості коефіиієнтів регресії проводили додаткові паралельні досліди для визначення дисперсії відтворюваності, тому в кожній точиі факторного простору проводилася серія із трьох дослідів. Однорідність дисперсії перевірялась за критерієм Кохрена та порівнювалась 3 табличним значенням.

Статистична обробка експериментальних даних полягала в обчисленні коефіиієнтів рівняння регресії та перевіриі їхньої значимості. Знайдені коефіиієнти рівняння регресії очінювали на статистичну значимість. Очінка проводилася за критерісм Стьюдента. Отримане рівняння регресії було перевірено на адекватність досліджуваного об'єкта, тобто спроможність його в достатній мірі описувати поверхню відгуку. Адекватність моделі перевіряли за критерісм Фімера. В результаті експерименту були отримані рівняння регресії в кодованому та натуральному вигляді. На підставі одержаних залежностей здійснена графічна інтерпретація математичної моделі у вигляді ізоповерхонь відгуку.

Застосування методів математичного моделювання дало змогу отримати параметри виробництва формованих картопляних чипсів підвищеної харчової иінності із заданими структурно-механічними показниками, що виливають на міцність кінцевого продукту.

Ключові слова: чипси, картопляна крупка, висівки, жмих гарбузового насіння, рівняння регресії, оптимізація.

Постановка проблеми. Останнім часом усе більше уваги приділяється питанню фізіологічно повноцінного харчування населення та безпечності харчових продуктів. Конкуренція на споживчому ринку постійно зростає, 
тому вимагає підвищення якості продуктів, що зумовлює науковців постійно вдосконалювати їх рецептурний склад. Проблема розробки продуктів функціонального призначення, що містять у необхідній кількості мікро- та макронутрієнти, вітаміни, харчові волокна, життєво необхідні для заповнення дефіциту есенціальних речовин, $є$ актуальною особливо для продуктів швидкого харчування, а саме: формованих картопляних чипсів.

Сьогодні, як правило, перш ніж запустити виробництво нового продукту, розробляється його рецептура. Розробка та вдосконалення рецептур нових видів продуктів пов'язані з дослідженням співвідношення вмісту окремих компонентів у готовому продукті. В ході вирішення цієї проблеми сукупність вимог до якості продукції формується у вигляді набору обмежень, які стосуються кількісного складу сировини та ії характеристик. Отож побудова математичної моделі для визначення впливу вмісту та характеристик інгредієнтів на якість готового продукту і встановлення на іï основі раціональних співвідношень, що забезпечать задані показники якості, $\epsilon$ актуальним завданням. Це дасть змогу отримати продукт з високими органолептичними показниками та розширити асортимент ринку чипсів [1].

Аналіз останніх досліджень і публікацій. Відомо, що чипси містять у своєму складі підвищений вміст крохмалю і фритюрного жиру, які при надмірному споживанні можуть спричинити ризик шлунково-кишкових, серцево-судинних захворювань тощо. Одним із шляхів вирішення вищезазначеної проблеми $\epsilon$ розробка технології формованих картопляних чипсів з підвищеною харчовою цінністю та без фритюрного жиру.

Виробництво формованих картопляних чипсів на ринку України тільки зароджується, оскільки основна сировина — картопляна крупка, надходить до України з Білорусі та Польщі. Діючими торговельними марками на ринку України $\epsilon$ «Золотисті» та «KartoFan», які пропонують широкий асортимент картопляних формованих чипсів з різними смаковими властивостями, проте 3 низькою харчовою цінністю [2].

Для підвищення харчової цінності формованих картопляних чипсів практичний інтерес представляє використання відходів із сільськогосподарської сировини: висівок жита, ячменю та жмиху гарбузового насіння.

Сучасні нутриціологи та дієтологи наголошують на необхідності споживання природних фізіологічно функціональних продуктів, що здатні запобігати різним захворюванням. Багатий інгредієнтний склад цих продуктів доповнюватиме харчовий раціон, сприятиме покращенню функціонування життєво важливих систем організму. Результати останніх досліджень доводять ефективність застосування математичного моделювання у розробленні рецептур з наперед заданими вимогами, що дасть змогу отримати продукти високої якості.

Метою дослідження $\epsilon$ розроблення рецептур формованих картопляних чипсів з частковою заміною картопляної крупки та повною заміною крохмалю висівками жита, ячменя та жмихом гарбузового насіння. Це надасть можливість покращити структурно-механічні властивості, підвищити харчову цінність готового продукту та, ймовірно, зменшити негативний вплив канцеро- 
генних речовин на організм людини, оскільки формовані картопляні чипси будуть випікатися і висушуватися без фритюрного жиру [3].

Матеріали і методи досліджень. Об'єкт дослідження - формовані картопляні чипси з висівками жита, ячменю та жмихом гарбузового насіння.

Технологічний процес виробництва формованих картопляних чипсів складається з внесення відповідної кількості картопляної крупки, висівок, жмиху, солі, води, їх замішування, формування та випікання-висушування. Часткова заміна картопляної крупки та повна заміна крохмалю на рослинну сировину підвищить харчову цінність готових виробів [4].

Розв'язання задачі та побудови плану експерименту здійснювали у два етапи:

- побудова математичної моделі, що буде відтворювати залежності між змінними, що досліджуються, і структурно-механічними властивостями готового продукту;

- знаходження фракційного складу висівок, кількості доданої води та температури випікання-висушування, що забезпечує максимальне наближення значення структурно-механічного показника готового продукту до бажаних значень.

Результати і обговорення. Визначення раціональних значень співвідношення компонентів 3 метою часткової заміни картопляної крупки та крохмалю на висівки й жмих гарбуза є складною технологічною задачею, тому їі вирішення проведено на основі математичного моделювання [5].

Для оцінки якості готового продукту за структурно-механічними показниками (міцність) був обраний вектор $Y$.

Для моделювання й оптимізації процесу виготовлення чипсів були проведені експериментальні дослідження. Для обробки результатів був застосований метод повного факторного експерименту (ПФЕ). При плануванні за схемою ПФЕ реалізуються всі можливі комбінації факторів на всіх обраних для дослідження рівнях. Для дворівневого ПФЕ необхідно провести $2^{k}$ дослідів. Рівні факторів представляють собою границі досліджуваної області за обраним параметром (мінімальне і максимальне значення фактора). ПФЕ дає можливість математично описати досліджуваний процес у певній локальній області факторного простору, яка лежить навколо вибраної точки й отримати математичний опис процесу у вигляді поліному $n$-степеня, тобто відрізком ряду Тейлора.

Для розроблення рівняння регресії було взято три фактори, що впливають на структурно-механічні показники (міцність) чипсів:

$X_{1}$ - ступінь подрібнення висівок, мкм;

$X_{2}$ - температура випікання-висушування, ${ }^{\circ} \mathrm{C}$;

$X_{3}$ - кількість доданої води, мл.

Фракційний склад висівок і жмиху визначали просіюванням на наборі сит 3 розмірами отворів $810-250$ мкм, температурний режим випікання-висушування підтримували в діапазоні $100-160^{\circ} \mathrm{C}$, а кількість води для приготування прийнятної консистенції напівфабрикату від 2,10-2,65 мл. на 1г сухої суміші. Значення обраних рівнів факторів варіювання наведено в табл. 1. 
Таблиця 1. Значення рівнів факторів та інтервал варіювання

\begin{tabular}{|c|c|c|c|c|}
\hline \multirow{2}{*}{ Досліджувані фактори } & \multicolumn{3}{|c|}{ Рівні варіювання } & \multirow{2}{*}{$\begin{array}{c}\text { Інтервал } \\
\text { варіювання }\end{array}$} \\
\hline & нижній & верхній & нульовий & \\
\hline$X_{1}$ - ступінь подрібнення висівок, мкм & 250 & 810 & 530 & 280 \\
\hline $\begin{array}{c}X_{2} \text { - температура випікання- } \\
\text { висушування, }{ }^{\circ} \mathrm{C}\end{array}$ & 100 & 160 & 130 & 30 \\
\hline$X_{3}$ - кількість доданої води, мл & 2,10 & 3,20 & 2,65 & 0,55 \\
\hline
\end{tabular}

Рівняння регресії оцінки структурно-механічних показників чипсів від ступеня подрібнення висівок, мкм; температури випікання-висушування, ${ }^{\circ} \mathrm{C}$; кількості доданої води, мл, буде мати вигляд:

$$
\begin{gathered}
Y\left(X_{1}, X_{2}, X_{3}\right)=b_{0}+b_{1} X_{1}+b_{2} X_{2}+b_{3} X_{3}+b_{4} X_{1} X_{2}+ \\
+b_{5} X_{1} X_{3}+b_{6} X_{2} X_{3}+b_{7} X_{1} X_{2} X_{3} .
\end{gathered}
$$

\begin{tabular}{|c|c|c|c|c|c|c|c|c|}
\hline \multirow{2}{*}{ № досліду } & \multicolumn{3}{|c|}{$\begin{array}{c}\text { Рівні факторів у } \\
\text { кодованому вигляді }\end{array}$} & \multicolumn{3}{|c|}{$\begin{array}{c}\text { Рівні факторів у } \\
\text { натуральному вигляді }\end{array}$} & \multirow{2}{*}{$Y_{\mathrm{cp}}$} & \multirow[t]{2}{*}{ Повторності } \\
\hline & $X_{1}$ & $X_{2}$ & $X_{3}$ & $X_{1}$ & $X_{2}$ & $X_{3}$ & & \\
\hline 1 & -1 & -1 & -1 & 250 & 100 & 2,10 & 2,3 & 2,$5 ; 2,2 ; 2,3$ \\
\hline 2 & +1 & -1 & -1 & 810 & 100 & 2,10 & 4,5 & 4,$0 ; 5,0 ; 4,5$ \\
\hline 3 & -1 & +1 & -1 & 250 & 160 & 2,10 & 8,5 & 8,$0 ; 9,0 ; 8,5$ \\
\hline 4 & +1 & +1 & -1 & 810 & 160 & 2,10 & 8,8 & 8,$5 ; 8,8 ; 9,0$ \\
\hline 5 & -1 & -1 & +1 & 250 & 100 & 3,20 & 6,8 & 6,$6 ; 6,8 ; 7,0$ \\
\hline 6 & +1 & -1 & +1 & 810 & 100 & 3,20 & 5,8 & 5,$5 ; 6,0 ; 5,8$ \\
\hline 7 & -1 & +1 & +1 & 250 & 160 & 3,20 & 9,8 & 10,$0 ; 9,5 ; 9,8$ \\
\hline 8 & +1 & +1 & +1 & 810 & 160 & 3,20 & 9,9 & 9,$8 ; 10,0 ; 10,0$ \\
\hline
\end{tabular}

Таблиця 2. Розширена матриця планування повного факторного експерименту $2^{3}$

Для перевірки значущості коефіцієнтів регресії проводили додаткові паралельні досліди для визначення дисперсії відтворюваності. Тому в кожній точці факторного простору проводилася серія з трьох дослідів.

При перевірці однорідності дисперсій за критерієм Кохрена було отримано розрахункове значення коефіцієнта Кохрена 0.326 , а табличне значення цього коефіцієнта $-0,5157$ для прийнятого рівня значущості $\alpha=5 \%$. Це означає, що $є$ можливість проводити подальший розрахунок коефіцієнтів.

Коефіцієнти рівняння регресії визначалися за формулами:

$$
\begin{gathered}
b_{0}=\frac{1}{N} \sum_{i=1}^{N} y_{i} ; \\
b_{j}=\frac{1}{N} \sum_{i=1}^{N} x_{j i} y_{i},
\end{gathered}
$$

де $X_{1}, X_{2}, X_{3}$ - фактори; $b_{0}$ - коефіцієнт, що характеризує вільний член рівняння; $b_{1}, b_{2}, b_{3}$ - коефіцієнти, що характеризують лінійні ефекти; $b_{4}, b_{5}$, $b_{6}, b_{7}$ - коефіцієнти, що характеризують ефекти взаємодії.

Статистична обробка експериментальних даних полягала в обчисленні коефіцієнтів рівняння регресії, перевірці їхньої значимості [6]. 
Оскільки матриця повного факторного експерименту є діагональною матрицею, то коефіцієнти регресії некорельовані між собою. Тому є можливість перевіряти значимість кожного коефіцієнта за критерієм Стьюдента, при цьому виключення з рівняння регресії (1) незначного коефіцієнта не позначиться на інших коефіцієнтах. Величини коефіцієнтів рівняння регресії характеризують внесок кожного фактора в величину $Y$.

Розрахувавши коефіцієнти, отримали таке рівняння регресії:

$$
\begin{gathered}
Y=7,046+0,196 X_{1}+2,196 X_{2}+1,021 X_{3}-0,087 X_{1} X_{2}- \\
-0,413 X_{1} X_{3}-0,412 X_{2} X_{3}+0,387 X_{1} X_{2} X_{3} .
\end{gathered}
$$

Знайдені коефіцієнти рівняння регресії оцінювали на статистичну значимість. Оцінка проводилася за критерієм Стьюдента. Розрахункові значення коефіцієнта Стьюдента $\left(t_{k}\right)$ для кожного коефіцієнта рівняння регресії надані в табл. 3.

\section{Таблиця 3. Розрахункові значення коефіціснтів рівняння регресії}

\begin{tabular}{|c|c|c|c|c|c|c|c|c|}
\hline & $b_{0}$ & $b_{1}$ & $b_{2}$ & $b_{3}$ & $b_{4}$ & $b_{5}$ & $b_{6}$ & $b_{7}$ \\
\hline$t_{k}$ & 111,501 & 3,099 & 34,749 & 16,155 & 1,385 & 6,528 & 6,528 & 6,132 \\
\hline
\end{tabular}

Табличне значення коефіцієнта Стьюдента дорівнює 2,12 при рівні статистичної значущості $\alpha=5 \%$ і числі степенів свободи 16. Згідно з даними табл. 3 рівняння регресії з урахуванням значимості коефіцієнтів за критерієм Стьюдента буде мати вигляд:

$$
\begin{gathered}
Y=7,046+0,196 X_{1}+2,196 X_{2}+1,021 X_{3}- \\
-0,413 X_{1} X_{3}-0,412 X_{2} X_{3}+0,387 X_{1} X_{2} X_{3} .
\end{gathered}
$$

Отримане рівняння регресії було перевірено на адекватність досліджуваного об'єкта, тобто спроможність його в достатній мірі описувати поверхню відгуку $(Y)$.

Адекватність моделі перевіряли за критерієм Фішера:

$$
F_{p}=\frac{S_{a d}}{S_{b}},
$$

де

$$
S_{a d}=\frac{m}{N-L} \sum_{i=1}^{N}\left(y_{i}-Y_{i}\right)^{2},
$$

де $N$ - кількість дослідів; $L-$ кількість значимих коефіцієнтів в рівнянні регресії; $m$ - кількість паралельних дослідів;

$$
S_{b}=\frac{1}{N} \sum_{i=1}^{N} S\left\{y_{i}\right\}
$$

де $S_{b}$ - дисперсія відтворюваності;

$$
S\left\{y_{i}\right\}=\frac{1}{n-1} \sum_{i=1}^{N}\left(y_{i}-\bar{y}_{i}\right)^{2},
$$

де $S\left\{y_{i}\right\}$ - дисперсія паралельних дослідів. 
Розрахункове значення критерію Фішера $F_{p}=1,917$ для рівняння регреciï (5), а табличне $F_{t a b}=2,4$ при рівні значущості $\alpha=5 \%$ і числі ступенів свободи 16.

Отже, рівняння регресії (5), отримане в результаті експерименту, адекватне досліджуваному об'єкту.

Рівняння регресії буде мати вигляд:

- у кодованій формі:

$$
\begin{array}{r}
Y=7,046+0,196 X_{1}+2,196 X_{2}+1,021 X_{3}- \\
-0,413 X_{1} X_{3}-0,412 X_{2} X_{3}+0,387 X_{1} X_{2} X_{3} ;
\end{array}
$$

- у натуральній формі:

$$
\begin{gathered}
Y=-35,423+0,037 X_{1}+0,257 X_{2}+12,295 X_{3}- \\
-0,0002 X_{1} X_{2}+0,014 X_{1} X_{3}-0,069 X_{2} X_{3}+0,00008 X_{1} X_{2} X_{3} .
\end{gathered}
$$

Графічне зображення рівняння (11) у вигляді поверхні відгуку і ліній рівня при фіксованому значенні ступені подрібнення висівок $X_{1}=530$ мкм представлено на рисунку.

Оптимізація технологічного процесу виробництва формованих картопляних чипсів показала, що максимальне значення структурно-механічних властивостей, а саме: міцність $Y=9,24$ досягається при сталому ступені подрібнення висівок $X_{1}=530$ мкм, температурі випікання-висушування $X_{2}=157^{\circ}-160^{\circ} \mathrm{i}$ кількості доданої води $X_{3}=2,43-2,65$ мл на 1 г суміші.
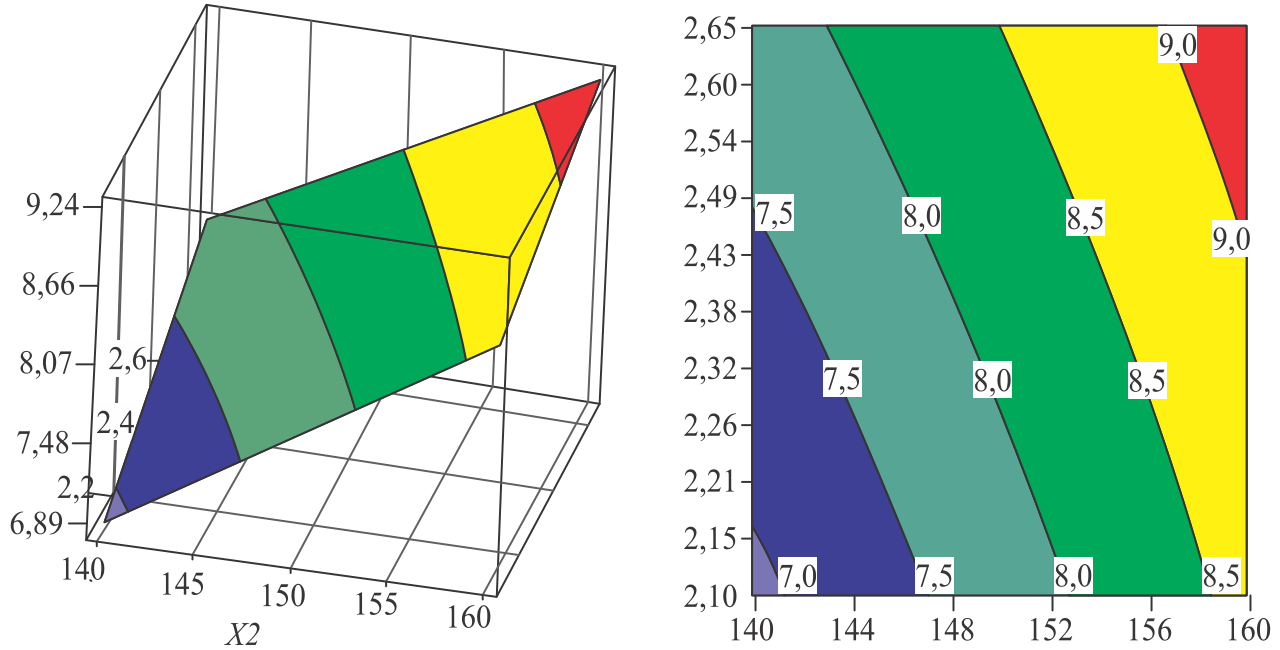

Рис. Графічне зображення рівняння у вигляді поверхні відгуку

\section{Висновки}

1. Побудовано регресійну модель технологічного процесу виробництва формованих картопляних чипсів. Встановлено співвідношення основних показників, що впливають на структурно-механічні показники, що дасть змогу отримати формовані картопляні чипси з оптимальними структурно-механічними показниками. 
2. Розроблена рецептура формованих картопляних чипсів може застосовуватися на підприємствах харчоконцентратної промисловості, оскільки для іiі реалізації не потребується жодних додаткових засобів.

\section{Література}

1. Сирохман I.В. Товарознавство харчових продуктів функціонального призначення: навч. посіб. [для студ. вищ. навчал. закл.] / І.В. Сирохман, В.М. Завгородня. - Київ : Центр учбової літератури, 2009. - С. 544.

2. Лисогор О.А. Сировина для виробництва картопляних чипсів / О.А. Лисогор, В.М. Ковбаса, Т.М. Купріянова // Збірник наукових праць «Продовольчі ресурси». Серія: Технічні науки. - 2014. - № 3 - С. $40-43$.

3. Kovalenko $O$. The use of stabilized fruin fat in the production of potato chips Food and Environment Safety / O. Kovalenko, V. Kovbasa, I. Radzievska // Food and Environment Safety. - 2016. - P. $249-254$.

4. Мир картофеля [Электронный ресурс]. — Режим доступу : htt://www.aviko.ru.

5. Запотоцька O.B. Комп'ютерна підтримка розробки рецептур для продуктів високотемпературної екструзії / О.В. Запотоцька, О.Л. Сєдих, В.М. Ковбаса // Sciense and Education a New Dimension. - 2013. - № 2 - C. 203-207.

6. Магомедов Г.О. Исследование оптимальных параметров замеса сбивного теста на основе муки из цельносмолотого зерна ржи, пшеницы и амаранта / Г.О. Магомедов, Т.А. Шевякова, Ю.А. Чернышева, Е.А. Мазина // Материалы III Международной научно-практической интернет-конференции. — Орел : УНПК, 2013. — С. 165-167. 